\title{
3. SHOREBASED INTERPRETATION OF DOWNHOLE MEASUREMENTS AT SITES 1065, 1068, AND 10691
}

\author{
H. Delius, ${ }^{2}$ S. Hunze, ${ }^{2}$ R. Pechnig, ${ }^{2}$ A. Bartetzko, ${ }^{2}$ J. Wohlenberg, ${ }^{2}$ and Shipboard Scientific Party ${ }^{3}$
}

\begin{abstract}
A reconstruction of the lithologies drilled during ODP Leg 173 has been performed using wireline logs. The electrofacies concept enables the characterization of nine different electrofacies in Holes 1065A, 1068A, and 1069A. The lithology of the logged sections consists of siliciclastic sequences of interbedded silts and clays containing calcareous-rich sediment layers. For each electrofacies a set of log responses was defined by threshold values of the most significant logs, in particular total gamma ray (SGR), photoelectric factor (PEF) and, in Hole 1065A, neutron porosity (APLC). The gamma ray reflects the clay content in these formations; the photoelectric effect is sensitive to the amount of calcium carbonate. As a result of applying the thresholds to the log data, continuous log-derived lithology profiles were established. The comparison of the log-lithology profiles with the core lithology is hampered by the low core recovery in the logged intervals. Besides the reconstruction of the log lithology, other sedimentological features also can be distinguished. For instance, trends in the gamma-ray log can be related to vertical changes in the clay content. The systematic log analysis presented here should be a useful complement to stratigraphic and sedimentological studies in these continental margin sequences.
\end{abstract}

\section{INTRODUCTION}

To study the ocean/continent transition (OCT) in the southern Iberia Abyssal Plain, drilling was performed at five sites during Ocean Drilling Program (ODP) Leg 173. Galicia Bank and the Iberia Abyssal Plain were first investigated during ODP Legs 103 (Boillot, Winterer, Meyer, et al., 1987) and 149 (Sawyer, Whitmarsh, Klaus, et al., 1994). Leg 149 drilled an east-west transect of holes off western Iberia (Fig. 1), and three holes penetrated basement. Subsequently, the main objective of Leg 173 was to investigate the nature and evolution of the basement within the OCT. Since the sedimentary section above acoustic basement was cored during Leg 149, during Leg 173 the boreholes were washed down to about $100 \mathrm{~m}$ above basement and cored mainly below this level. Holes 1065A, 1068A, and 1069A were logged by Schlumberger logging tools. At Holes 1068A and 1069A, only a small overlap exists between the cored and the logged intervals (Fig. 2).

The major aim of this paper is to interpret the logging data to provide a detailed lithological reconstruction and to make the results available for the shipboard scientific party for further investigations. Interpretation of well logging data can provide information on the lithology, stratigraphy, and mineralogy of the wall rocks. This is especially important in holes with rather low core recovery, such as those drilled during Leg 173. In sections with high core recovery, logging data provides additional information that complements core description and core measurements. Interpretation of Leg 173 well logs was performed to: (1) identify the major lithologies, particularly in intervals that were not cored, (2) reconstruct a continuous lithological profile, (3) characterize the lithologies by their in-situ physical properties, (4) detect boundaries of sedimentary units, and (5) identify trends that might be related to gradual changes in the sedimentation history.

${ }^{1}$ Whitmarsh, R.B., Beslier, M.-O., Wallace, P.J., et al., 1998. Proc. ODP, Init. Repts., 173: College Station, TX (Ocean Drilling Program).

${ }^{2}$ Lehr- und Forschungsgebiet für Angewandte Geophysik, Rheinisch-Westfälische Technische Hochschule Aachen, Lochnerstr. 4-20, D-52056 Aachen, Federal Republic of Germany. heike@sun.geophac.rwth-aachen.de

${ }^{3}$ Shipboard Scientific Party is given in the list preceding the Table of Contents.

\section{METHODOLOGY}

The chosen log interpretation strategy is based on the electrofacies concept (Serra, 1984). An electrofacies is defined as an individual set of log responses that is characteristic for a particular lithology. Usually it is necessary to calibrate logging data with core information from key intervals. This approach was limited in Leg 173 by the performed drilling and coring program. The logged intervals of Holes 1068A and 1069A are mostly not cored and in Hole 1065A the core recovery is very low. Therefore, the lithostratigraphy of the cored sediments from the adjacent Hole 900A (Sawyer, Whitmarsh, Klaus, et al., 1994) was used as basic information for this study. Figure 2 gives an overview of the logged intervals in Holes 900A, $1065 \mathrm{~A}, 1068 \mathrm{~A}$, and 1069A. Hole $900 \mathrm{~A}$ is located about $600 \mathrm{~m}$ and $16 \mathrm{~km}$ east of Holes $1068 \mathrm{~A}$ and $1069 \mathrm{~A}$, respectively, and $25 \mathrm{~km}$ west of Hole 1065A (see Fig. 1). The sediments recovered in Hole 900A are mainly composed of siliciclastics like clay, silt, and sand, as well as of calcareous and dolomitic constituents, generally similar to those recovered during Leg 173 . We simplified the use of the terms "clay," "silt," and "sand" to better grasp the changing proportion of $\mathrm{SiO}_{2}$. The grain-size change is not of primary interest. A calibration, in the sense of relating logging data directly to equivalent core data, was not feasible, and a quantitative estimation of the different components in the mixed sediment has not been given. Hole 900A was logged in short intervals and the core recovery was mainly low. We used the lithological information of Hole 900A and Leg 173 holes qualitatively, that is, to learn which lithologies generally occur.

It is important to consider that the vertical resolution of the tools is about $30 \mathrm{~cm}$. This means that single layers $(<30 \mathrm{~cm})$ in fine-scaled alternating sequences and beds of centimeter thickness cannot be identified, but the whole sequence produces an average log response. The sampling interval of the logging data is $15.24 \mathrm{~cm}$ (6 in).

The most useful logs for distinguishing these sediments are the SGR (total gamma ray) and the PEF (photoelectric factor). The gamma ray $\log$ is useful to detect the clay content in formations that contain no radioactive minerals other than clays (Schlumberger, 1989; Serra, 1984). In these dominantly pelagic sediments, we assume that the radioactivity is associated with clay mineral content (Fig. 3). There is no indication from available core analyses that quartz sands or calcareous sediments are enriched in radioactive minerals. The 


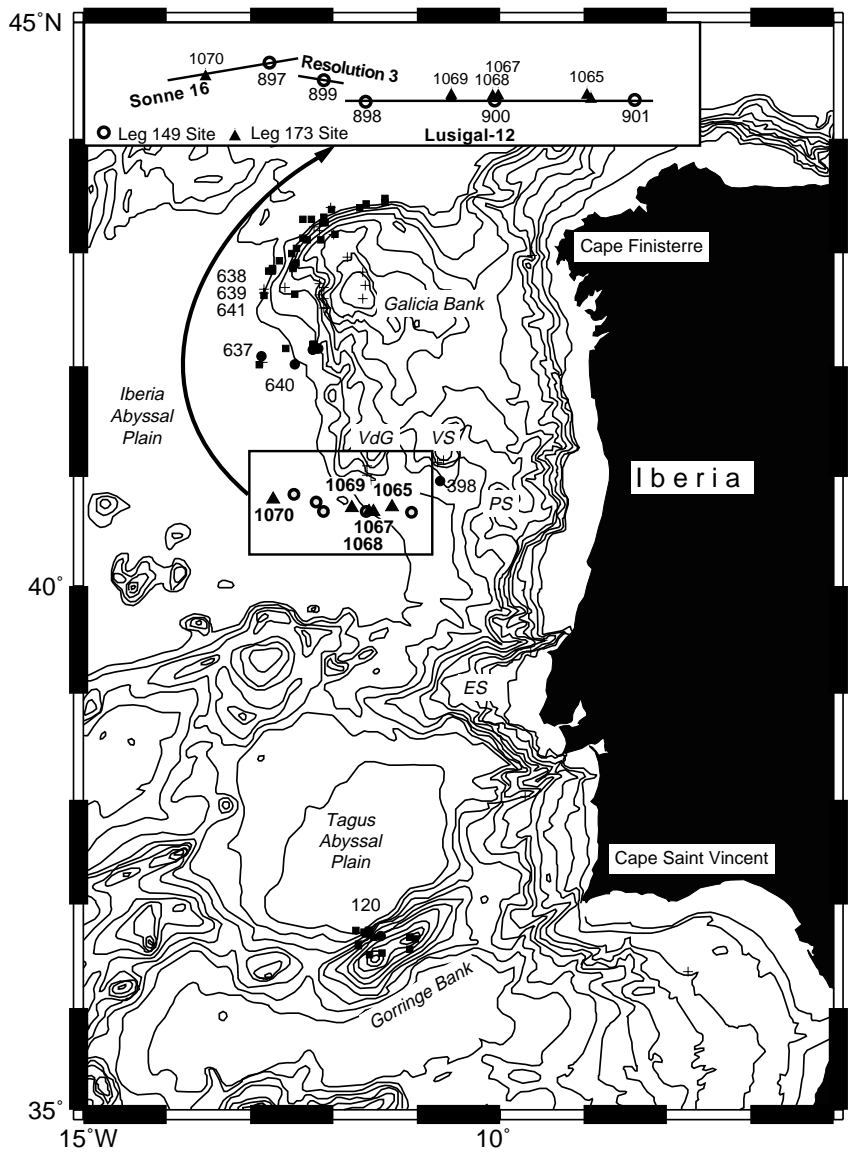

Figure 1. Location map of sites drilled during Leg 173 (black triangles) and Leg 149 (open circles).

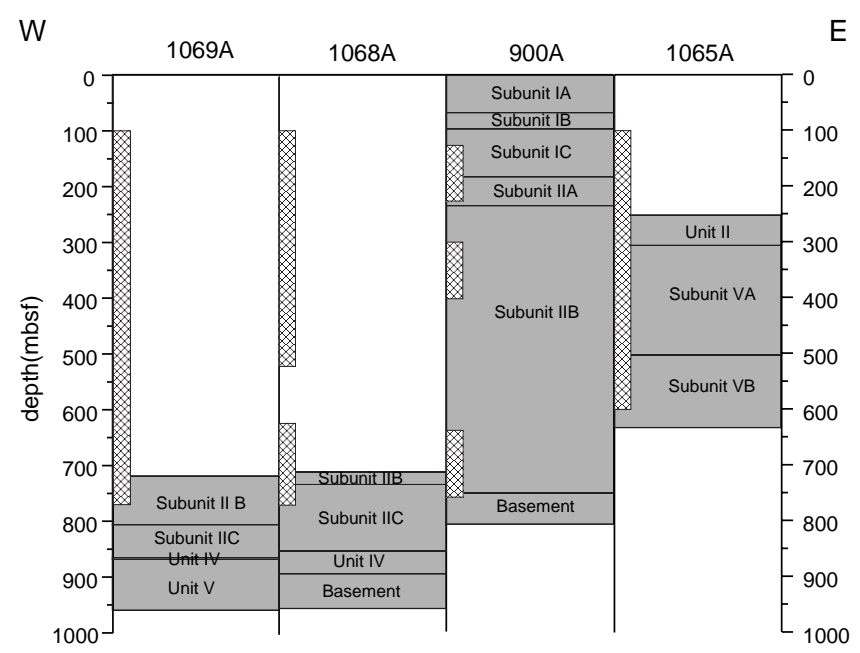

logged interval

cored interval

Figure 2. Overview of the logged and cored intervals in Holes 900A, 1065A, 1068A, and 1069A.

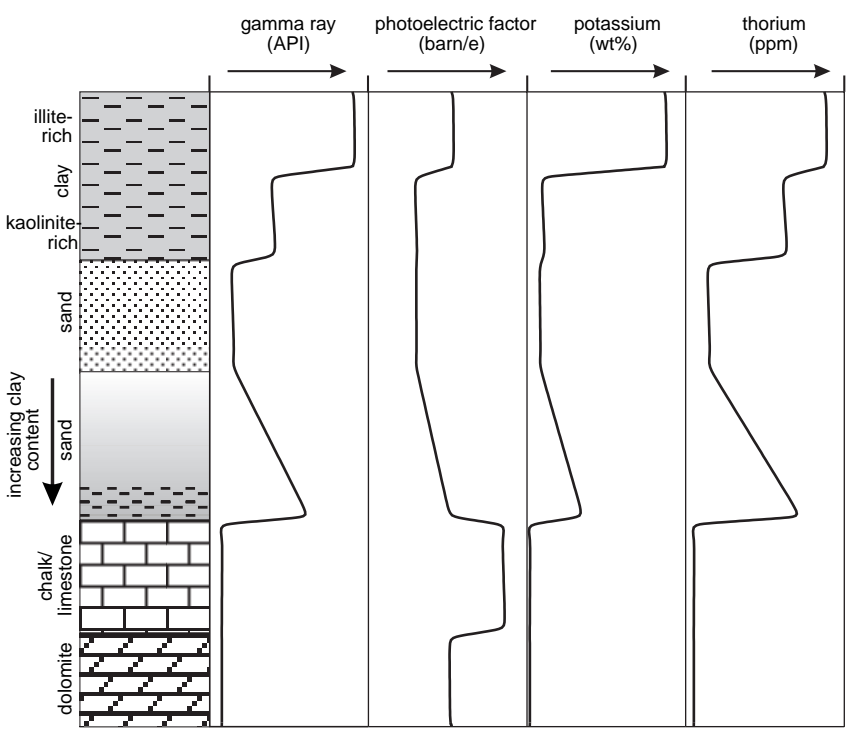

Figure 3. Schematic presentation of typical relations in log responses of the gamma ray, the photoelectric factor as well as the potassium and thorium content for the most common rock types logged during Leg 173. The arrows indicate a general increase of the values. The figure is composed after Serra (1986), Schlumberger (1988), and Rider (1996).

high gamma-ray values observed are related to increased potassium and thorium contents in the clay minerals. Reference values for the main components are taken from Schlumberger (1972): average clay/ claystone 80-140 API units, quartz sand/sandstone 10-30 API, limestone 5-10 API. Corresponding to these values and to the known lithology of Hole 900A, threshold values were defined for the pure end-members clay ( $>80$ API) and quartz sand/calcareous ooze $(<25$ API). SGR values between 25 and 80 were subdivided to classify the mixed siliceous sediments such as silt and silty clay. The photoelectric factor $\log (\mathrm{PEF})$ was used as an indicator for calcite content. Pure calcite has the highest PEF (5.08 barn/e) compared to dolomite (3.14 barn/e), clays ( 1.83 barn/e for kaolinite and 3.45 barn/e for illite), and quartz (1.81 barn/e; Serra, 1984). In Hole 1065A, high calcite content produces PEF values greater than 3 barn/e in some sections. According to Sawyer, Whitmarsh, Klaus, et al. (1994) mixtures of illite and kaolinite were recovered in the boreholes of Leg 149. Therefore, we can assume that clay intervals have a PEF below 3 barn/e. The crossplot in Figure 4 shows the correlation of SGR and PEF for clayey and calcareous sediments. An increase in the PEF, combined with an increase in the SGR, reflects an enriched clay content. For the dominantly calcareous sediments, a negative correlation of PEF and SGR underlines the effect of the calcareous minerals on the PEF measurements. Dolomitic sediments occur only in Hole 1065A, but they cannot be determined from the logs because they do not exhibit significant PEF and SGR values.

The density, electrical resistivity, and neutron porosity measurements are sensitive to porosity changes in the formation. Pelagic sediments generally have significant porosity and porosity variations that are not primarily related to changes in the chemical composition. However, depending on induration or burial depth, the same lithology shows different bulk density and resistivity responses. Hence, the general decrease of the pore volume with depth resulting from diagenesis makes it difficult to use these porosity-sensitive logs for lithologic distinction. In Hole 1065A, sections with resistivity $<1$ $\Omega \mathrm{m}, \mathrm{PEF}<1 \mathrm{barn} / \mathrm{e}$, and neutron porosity $>80 \%$ occur. These mea- 


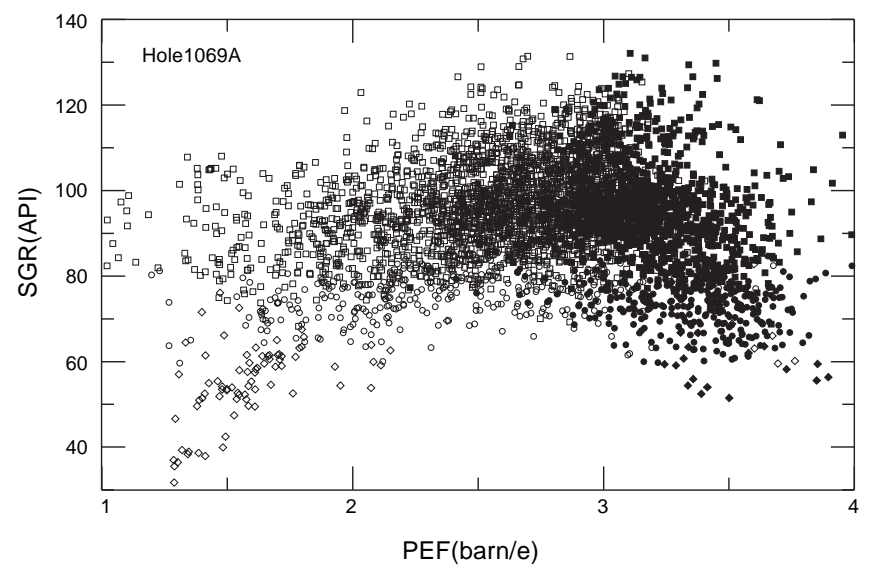

Figure 4. Crossplot of PEF data vs. SGR data in Hole 1069A. Two different correlations are evident. There exists a positive correlation of PEF and SGR for clayey sediments (open symbols), and a negative correlation for calcareous sediments (filled symbols).

surements indicate that the physical properties of seawater (Serra, 1984) were measured and that the hole is very enlarged (>16 in). Although these intervals are characterized by bad hole conditions, even the bad hole was used as an indicator for lithologies such as quartz sand or calcareous ooze that cause unstable borehole walls. It is not possible to classify unequivocally either unconsolidated quartz sand or calcareous ooze in these sediments as the only helpful log (PEF) is not reliable. The neutron log device was used for the separation of the electrofacies chalk and quartz sand/calcareous ooze. Both lithologies exhibit low gamma-ray values but probably have different physical properties. "Chalk" is by definition partially lithified sediment and "ooze" is unlithified (Sawyer, Whitmarsh, Klaus, et al., 1994); thus, low gamma-ray values combined with neutron porosity lower than $70 \%$ were classified as chalk.

Based on the presented relations between SGR and PEF, and the neutron porosity log, threshold values were defined for nine electrofacies (Table 1). These thresholds were used to distinguish manually the main rock types within the logged intervals and to create continuous lithological profiles for Sites 1065, 1068, and 1069. The nine electrofacies are not present in all Leg 173 holes. The correlation of core lithology to log lithologies is necessary to estimate the reliability and to confirm the nomenclature adopted from the cores. The terminology of the electrofacies follows the lithology based on core description (see "Lithostratigraphy" section, "Explanatory Notes" chapter, this volume).

In addition, discriminant analysis was performed on the data set to test the reliability of automated prediction of lithologies. The discriminant analysis can be used to (1) assess the accuracy of a predefined classification, and (2) classify unclassified cases (Backhaus et al., 1989). The analysis focuses on the calculation of linear discriminant functions that best separate different classes. Before calculating a discriminant function, the classes need to be assigned in a training set. Here, classes are identical with electrofacies. For this study, discriminant analysis was mainly used for the first option. It is necessary to integrate all available logs because for the discriminant analysis it is advisable to use at least as many variables $(=\operatorname{logs})$ as predetermined classes (Backhaus et al., 1989). As a check, the discriminant analysis results were compared to manual determination of lithology using the thresholds of Table 1. Only as a test, the second option was performed on Leg 173 data. Results of the discriminant analysis are presented in the summary section.
Table 1. Classification criteria and log value limits for the electrofacies.

\begin{tabular}{|c|c|c|c|c|c|}
\hline Electrofacies & $\begin{array}{l}\text { SGR } \\
\text { (API) }\end{array}$ & $\begin{array}{c}\text { PEF } \\
\text { (barn/e) }\end{array}$ & $\begin{array}{l}\text { Potassium } \\
\text { (wt } \%)\end{array}$ & $\begin{array}{c}\text { Thorium } \\
\text { (ppm) }\end{array}$ & $\begin{array}{l}\text { APLC } \\
(\%)\end{array}$ \\
\hline Quartz sand/calcareous ooze & $<25$ & $<2$ & $<0.6$ & $<3$ & high \\
\hline Nannofossil chalk & $<25$ & - & $<0.7$ & $<3.5$ & low \\
\hline Nannofossil chalk with clay & $25-40$ & - & $0.5-1.0$ & $2-6$ & - \\
\hline Silt/siltstone & $40-60$ & $<3$ & $0.5-1.7$ & $4-11$ & - \\
\hline Calcareous silt/siltstone & $40-60$ & $>3$ & $0.5-1.7$ & $4-11$ & - \\
\hline Silty clay/claystone & $60-80$ & $<3$ & $1.3-2.0$ & $6-12$ & - \\
\hline Calcareous silty clay/claystone & $60-80$ & $>3$ & $1.3-2.0$ & $6-12$ & - \\
\hline Clay/claystone & $>80$ & $<3$ & $1.5-2.7$ & $8-18$ & - \\
\hline Calcareous clay/claystone & $>80$ & $>3$ & $1.5-2.7$ & $8-18$ & - \\
\hline
\end{tabular}

Note: $\mathrm{SGR}=$ total gamma ray; $\mathrm{PEF}=$ photoelectric factor; $\mathrm{APLC}=$ neutron porosity

Further details about log interpretation methods used in this study can be found in Rider (1996), Schlumberger (1989), and Serra (1986). Additional information about the use of discriminant analysis for the interpretation of well-logging data can be found in Doveton (1994).

\section{RESULTS OF LOG INTERPRETATION}

\section{Hole 1065A: Description of the Log Lithology Profile}

Hole $1065 \mathrm{~A}$ was drilled to a depth of $251 \mathrm{mbsf}$ and then cored to a total depth (TD) of 631 mbsf. The core recovery was very low (12.5\%). Downhole measurements were logged between 600 and 100 mbsf. The data quality is discussed in the "Downhole Measurements" section of the "Site 1065" chapter, this volume, and in Section 7, "Shorebased Processed Logs," on CD-ROM (back pocket, this volume).

Based on the amount of siliceous and calcareous material and the grade of lithification, seven of the nine electrofacies were identified by the total gamma ray (SGR), photoelectric factor (PEF), and neutron porosity (APLC). In discrete depth intervals, PEF shows erroneous data which had to be eliminated; in consequence, the PEF log contains gaps. In the depth interval between 135 and 105 mbsf, invalid PEF values $(<1$ barn/e) prevent log interpretation. The key log for the discrimination is the SGR. The seven electrofacies that occur are quartz sand/calcareous ooze, nannofossil chalk, nannofossil chalk with clay, silt/siltstone, calcareous silt/siltstone, silty clay/claystone and calcareous silty clay/claystone. The lithological profile reconstructed by the logging data is shown in Figure 5. The average log values of these lithologies are given in Table 2. The dominant electrofacies are silty clay/claystone and silt/siltstone.

Generally the gamma ray curve was used for the determination of increasing or decreasing clay content. In the logging data, small-scale trends can be observed. In Figure 5 arrows point to the clearest trends. The observed upward increases in gamma ray (clay content) are probably caused by turbidites becoming systematically finer grained and thinner over distances of several meters. In the depth interval from 535 to 515 mbsf, below the boundary between Subunits VB and VA, six such trends are identified. Individual turbidites generally have thicknesses of only a few centimeters (see "Lithostratigraphy" section, "Site 1065" chapter, this volume). Consequently, in the logs a single trend will consist of several turbidites.

In addition to the gamma-ray log, the electrical resistivity log was particularly useful in this hole as an indicator of abrupt diagenetic changes. At $515 \mathrm{mbsf}$, there is a change in the resistivity and the photoelectric factor. This change corresponds to the lithostratigraphic boundary between lithostratigraphic Subunits VA and VB, the latter of which contains dolomitized claystone and siltstone. The dolomitization below $515 \mathrm{mbsf}$ leads to somewhat better hole conditions and 

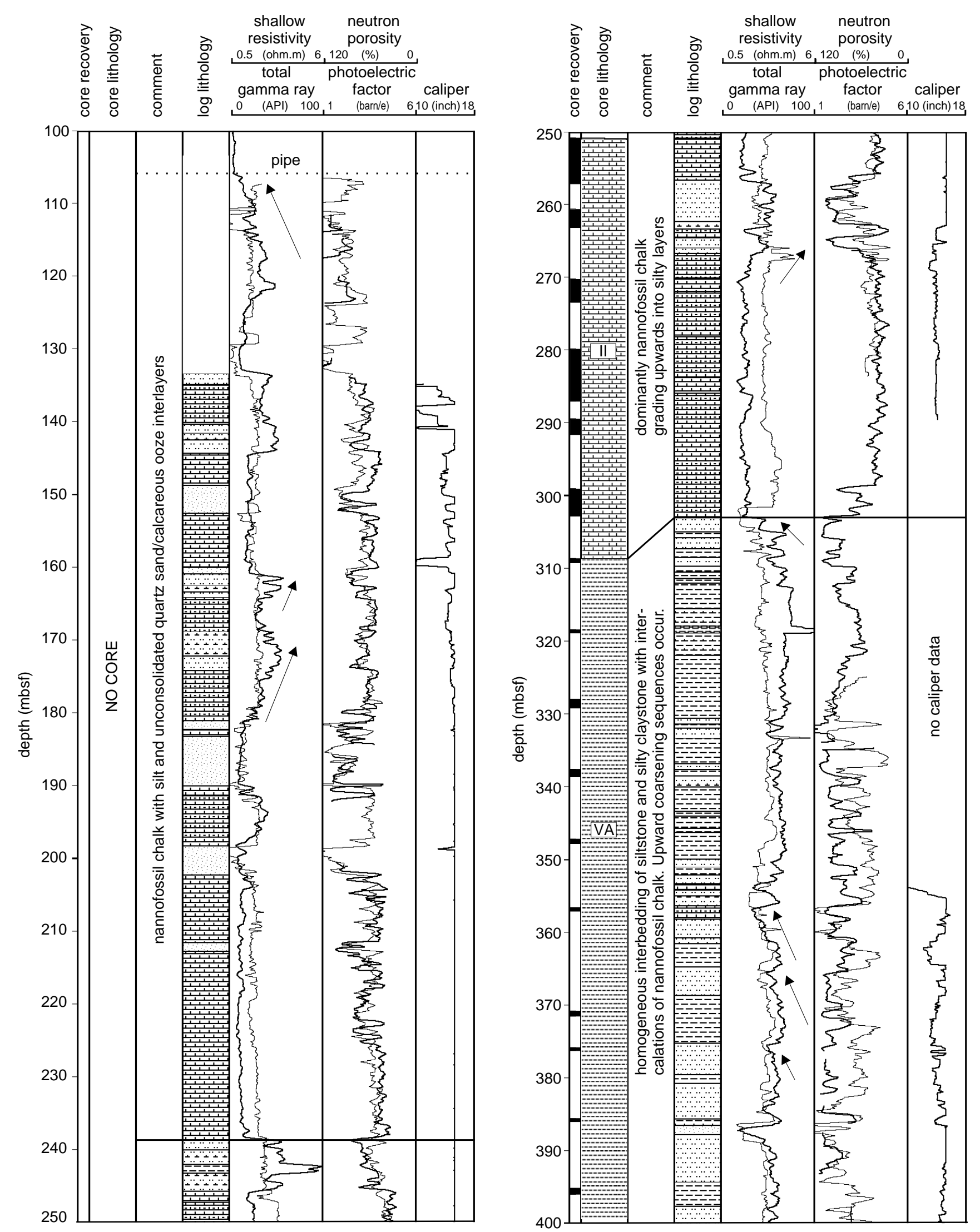

Figure 5. Hole 1065A: lithostratigraphic reconstruction of the drilled lithologies based on the logging data. The comments refer to the log lithology column. The left column displays the generalized core lithology, which is not as detailed as the core description (see "Lithostratigraphy" section, "Site 1065" chapter, this volume). Arrows mark trends in the logs that can be related to systematic lithological changes. SGR and PEF are shown by bold lines. (Continued next page.) 

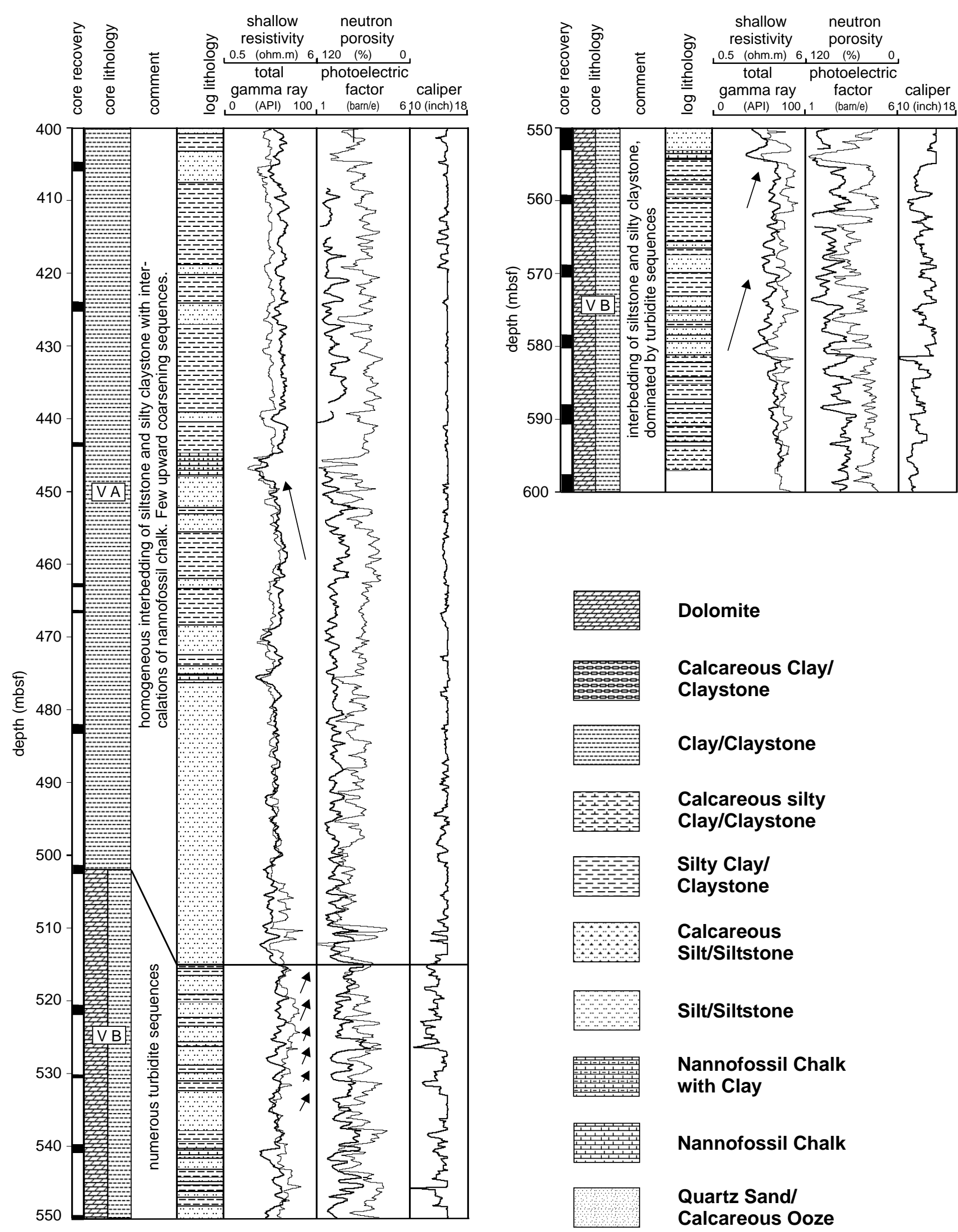
Table 2. Hole 1065A average and standard deviation of $\log$ values calculated for the electrofacies determined by log analysis (see text).

\begin{tabular}{|c|c|c|c|c|c|c|c|c|c|}
\hline Electrofacies & $\begin{array}{l}\text { SGR } \\
\text { (API) }\end{array}$ & $\begin{array}{c}\text { PEF } \\
\text { (barn/e) }\end{array}$ & $\begin{array}{l}\text { Potassium } \\
\text { (wt } \%)\end{array}$ & $\begin{array}{l}\text { Uranium } \\
\text { (ppm) }\end{array}$ & $\begin{array}{c}\text { Thorium } \\
\text { (ppm) }\end{array}$ & $\begin{array}{c}\text { APLC } \\
(\%)\end{array}$ & $\begin{array}{l}\text { RHOB } \\
\left(\mathrm{g} / \mathrm{cm}^{3}\right)\end{array}$ & $\begin{array}{l}\text { SFLU } \\
(\Omega \mathrm{m})\end{array}$ & $\begin{array}{l}\text { IDPH } \\
(\Omega \mathrm{m})\end{array}$ \\
\hline Quartz sand/calcareous ooze (210) & $16 \pm 6.1$ & $2.2 \pm 0.9$ & $0.4 \pm 0.2$ & $0.5 \pm 0.3$ & $1.8 \pm 0.8$ & $103 \pm 20.9$ & $1.6 \pm 0.3$ & $0.7 \pm 0.2$ & $0.1 \pm 0.1$ \\
\hline Nannofossil chalk (460) & $16 \pm 5.4$ & $3.8 \pm 0.7$ & $0.4 \pm 0.2$ & $0.5 \pm 0.3$ & $1.8 \pm 0.9$ & $60 \pm 11$ & $1.8 \pm 0.3$ & $1.1 \pm 0.3$ & $1.3 \pm 0.3$ \\
\hline Nannofossil chalk with clay (475) & $31 \pm 6.0$ & $3.5 \pm 1.0$ & $0.7 \pm 0.2$ & $0.9 \pm 0.3$ & $3.8 \pm 1.1$ & $66 \pm 22$ & $1.8 \pm 0.3$ & $1.4 \pm 0.5$ & $1.5 \pm 0.5$ \\
\hline Silt/siltstone (967) & $53 \pm 5.6$ & $2.1 \pm 0.5$ & $1.4 \pm 0.2$ & $1.4 \pm 0.4$ & $5.8 \pm 1.1$ & $72 \pm 16$ & $2.1 \pm 1.3$ & $1.9 \pm 0.6$ & $2.4 \pm 0.7$ \\
\hline Calcareous silt/siltstone (110) & $51 \pm 7.4$ & $3.3 \pm 0.6$ & $1.2 \pm 0.3$ & $1.4 \pm 0.5$ & $6.1 \pm 1.0$ & $60 \pm 16$ & $1.9 \pm 0.3$ & $1.5 \pm 0.6$ & $1.7 \pm 0.7$ \\
\hline Silty clay/claystone (829) & $64 \pm 4.5$ & $2.2 \pm 0.5$ & $1.7 \pm 0.2$ & $1.6 \pm 0.6$ & $6.7 \pm 1.0$ & $58 \pm 16$ & $2.3 \pm 1.6$ & $2.1 \pm 0.7$ & $2.5 \pm 0.8$ \\
\hline Calcareous silty clay/claystone (140) & $68 \pm 4.9$ & $3.3 \pm 0.3$ & $1.7 \pm 0.2$ & $2.0 \pm 0.8$ & $6.9 \pm 1.2$ & $47 \pm 20$ & $2.3 \pm 0.2$ & $2.5 \pm 1.0$ & $2.9 \pm 1.0$ \\
\hline
\end{tabular}

Note: Number of data points for each electrofacies is given in parentheses. SGR = total gamma ray; PEF = photoelectric factor; APLC = neutron porosity; RHOB = density; SFLU = shallow resistivity; IDPH = deep resistivity.

also increased core recovery with the resulting hole diameter less enlarged than in the section above (Fig. 28, "Downhole Measurements" section, "Site 1065" chapter, this volume). At 303 mbsf the change from lithostratigraphic Subunit VA to Unit II can be identified by a sharp decrease of the gamma ray. Subunit VA is dominated by the electrofacies silty clay/claystone and silt/siltstone; Unit II mainly consists of the electrofacies clayey nannofossil chalk. At $238 \mathrm{mbsf}$, a decrease in resistivity indicates a change from lithified sediments to less lithified sediments above. This could be related to the boundary from Unit II to Unit I defined at Site 900 (Sawyer, Whitmarsh, Klaus, et al., 1994). Unit I is dominated by siliciclastic muddy turbidites capped by pelagic nannofossil ooze. This observation corresponds well with the log-derived lithology; as in Figure 5, the interval above $238 \mathrm{mbsf}$ is dominated by nannofossil chalk. Intercalations of very unconsolidated layers can be identified as quartz sand or calcareous ooze. This electrofacies is limited to this section and does not occur in any of the other logged holes.

Comparison of core and logging data is hampered by poor core recovery. The recovery is fairly low below $310 \mathrm{mbsf}$ and the generalized lithological profile does not represent the diversity of the lithologies. The log lithology profile shows a greater variety of electrofacies, but regarding the detailed core description available from the barrel sheets, a similar variety of lithologies can be recognized. Rock types occurring in Hole 1065A are nannofossil chalk and nannofossil claystone in lithostratigraphic Unit II, claystone, calcareous claystone, sandstone, and conglomerate in Subunit VA, and claystone/dolomitic claystone, dolomitic silty claystone and siltstone, sandstone, and conglomerate in Subunit VB (see "Lithostratigraphy" section, "Site 1065" chapter, this volume). The log-derived lithology, however, reveals higher proportions of silty and sandy material in Subunit VA than was observed in the cores. This might be a hint that core loss is related to the occurrence of these sediments. On the other hand, the calcareous proportion corresponds well with the occurrence of calcareous sediments in Cores 173-1065A-9R and 12R.

In order to check the statistical robustness of the seven electrofacies that we identified, discriminant analysis was carried out using the spectral gamma-ray logs, photoelectric factor, density, porosity, and resistivity logs. In Hole $1065 \mathrm{~A}, 85.42 \%$ of the depth points agreed with the manually classified electrofacies. This result indicates a very good delineation of the electrofacies.

\section{Hole 1068A: Description of the Log Lithology Profile}

Hole 1068A was drilled to a depth of $711.3 \mathrm{mbsf}$ and then cored to a TD of 955.8 mbsf. The core recovery was $73.9 \%$. Downhole measurements were obtained within two intervals from 768 to 614 mbsf and from 507 to 114 mbsf. Although log interpretation was carried out in the depth interval from 350 to $450 \mathrm{mbsf}$, this section should be regarded with caution because of uncertain hole conditions. The data quality is discussed in the "Downhole Measurements" section, "Site 1068" chapter, this volume, and in Section 7, "Shorebased Processed Logs," on CD-ROM (back pocket, this volume).

Related to the amount of siliceous and calcareous material and the grade of lithification, six of the nine electrofacies were distinguished by the SGR and PEF (see also "Downhole Measurements" section, "Site 1068" chapter, this volume). The six electrofacies are silt/siltstone, calcareous silt/siltstone, silty clay/claystone, calcareous silty clay/claystone, clay/claystone, and calcareous clay/claystone. The lithological profile reconstructed by the logging data is shown in Figure 6 . The average log values of these lithologies are given in Table 3 . The dominant electrofacies is clay/claystone, followed by silty clay/claystone and calcareous silty clay/claystone. The minor electrofacies are calcareous silt/siltstone and silt/siltstone.

The lowermost logged interval (768 to $614 \mathrm{mbsf}$ ) covers the lithostratigraphic Subunits IIB and IIC. The boundary between these two lithostratigraphic units was defined in the cores based on a change in sediment succession, but it is not evident in the logs. This interval is characterized by the electrofacies clay/claystone, partly calcareous, with interbedding of silty clay/claystone and silt/siltstone. The section from 505 to 467 mbsf is homogeneously composed of clay with calcareous clayey parts. At $467 \mathrm{mbsf}$ a decrease of the gamma-ray log and an increase of the neutron porosity log mark a change in the sedimentation. Between 467 and $236 \mathrm{mbsf}$, two cycles can be observed (1: 467-343 mbsf, 2: 343-236 mbsf). Each cycle starts with thin silty layers at the base (1: 467-442, 2: 343-307 mbsf) and toward the top becomes homogeneous and clayey. At 236 mbsf, a decrease of the gamma ray log and an increase of the photoelectric factor log mark the transition to the subsequent more calcareous and less clayey sediments. Above $204 \mathrm{~m}$ four upward-fining sequences can be distinguished.

The electrofacies identified from the log lithology profile are in agreement with the lithologies defined from cores. The main rock types occurring in Hole 1068A within the logged interval are calcareous claystone, claystone, and calcareous siltstone in lithostratigraphic Subunit IIB, claystone, calcareous claystone, nannofossil chalk, and calcareous sandy siltstone in Subunit IIC (see "Lithostratigraphy" section, "Site 1068" chapter, this volume). In the log lithology column between 710 and 745 mbsf we find claystone and calcareous claystone. Compared to the barrel sheets it seems to be less calcareous, but one should take into consideration that in the core analysis the estimation of the calcite was not done quantitatively and therefore the amount can be variable. Below $750 \mathrm{mbsf}$, the sediments in the core are less calcareous and more silty. This change corresponds to 748 mbsf in the logs.

Discriminant analysis was carried out using the spectral gamma ray logs, photoelectric factor, density, porosity, and resistivity logs. In Hole 1068A, $79.0 \%$ of the depth points agreed with the six electrofacies that were manually classified. This result indicates a good delineation of the electrofacies.

\section{Hole 1069A: Description of the Log Lithology Profile}

Hole 1069A was drilled to a depth of $718.8 \mathrm{mbsf}$ and then cored to a TD of 959.3 mbsf. The core recovery was $40 \%$. Downhole measurements were obtained from 778 to 102 mbsf. The data quality is discussed in the "Downhole Measurements" section in the "Site 1069" chapter, this volume, and in Section 7, "Shorebased Processed Logs," on CD-ROM (back pocket, this volume). 

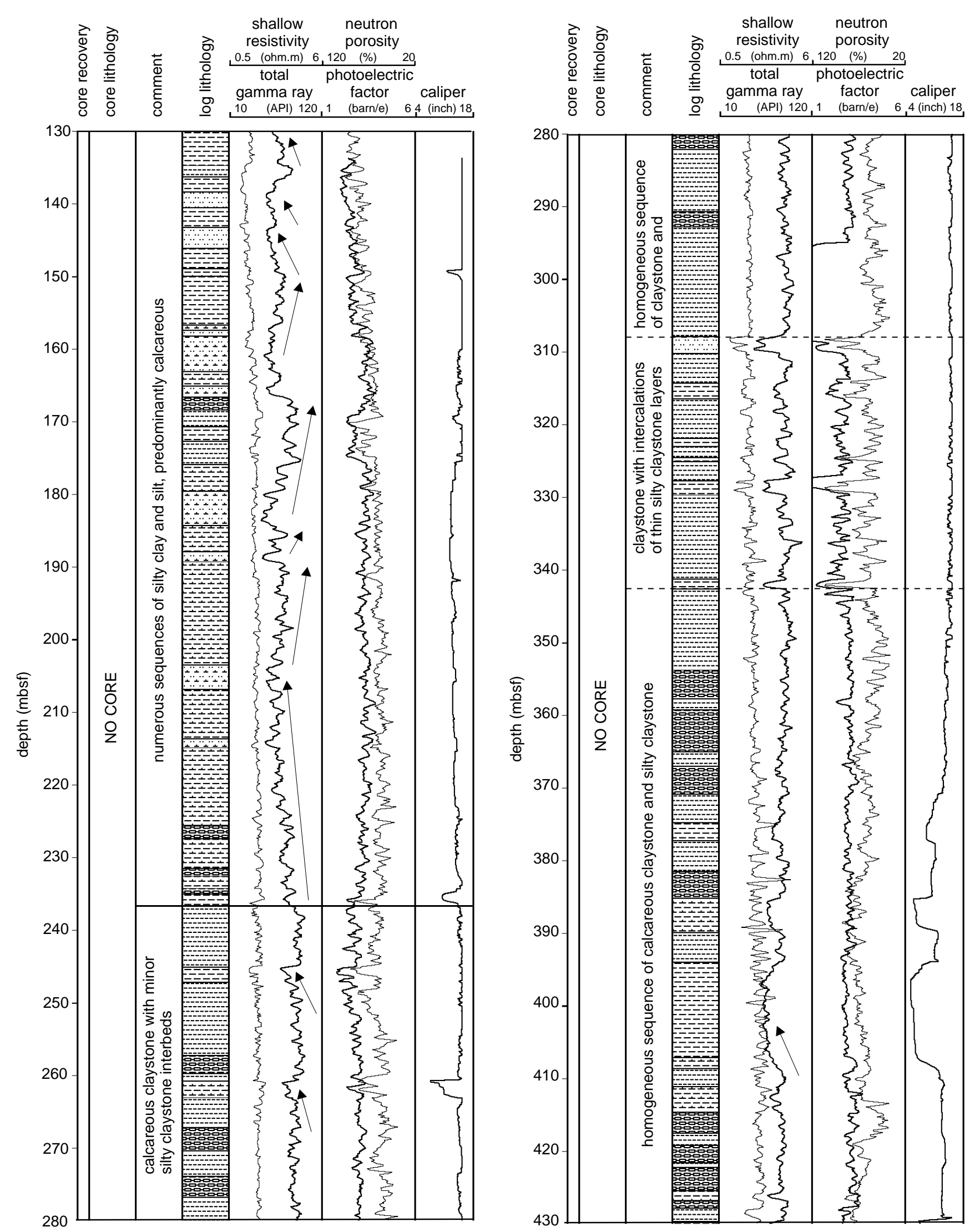

Figure 6. Hole 1068A: lithostratigraphic reconstruction of the drilled lithologies based on the logging data. Arrows mark trends in the logs that can be related to systematic lithological changes. The comments refer to the log lithology column. The left column displays the generalized core lithology, which is not as detailed as the core description (see "Lithostratigraphy" section, "Site 1068" chapter, this volume). For the explanation of the patterns see Figure 5. SGR and PEF are shown by bold lines. (Continued next page.) 

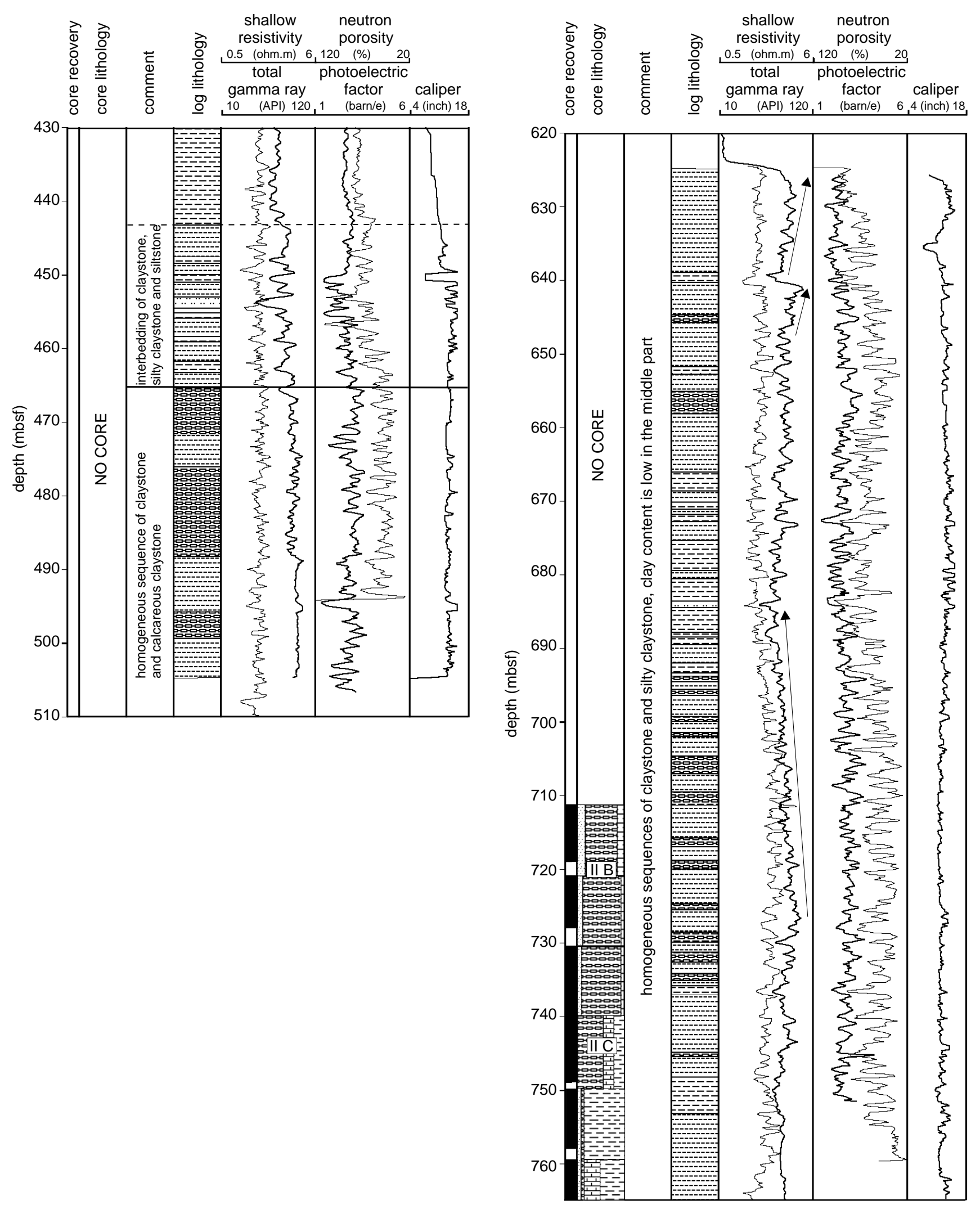

Figure 6 (continued). 
Table 3. Hole 1068A average and standard deviation of log values calculated for the electrofacies determined by log analysis (see text).

\begin{tabular}{|c|c|c|c|c|c|c|c|c|c|}
\hline Electrofacies & $\begin{array}{l}\text { SGR } \\
\text { (API) }\end{array}$ & $\begin{array}{c}\text { PEF } \\
\text { (barn/e) }\end{array}$ & $\begin{array}{l}\text { Potassium } \\
\quad(w t \%)\end{array}$ & $\begin{array}{c}\text { Uranium } \\
\text { (ppm) }\end{array}$ & $\begin{array}{l}\text { Thorium } \\
\text { (ppm) }\end{array}$ & $\begin{array}{c}\text { APLC } \\
(\%)\end{array}$ & $\begin{array}{l}\text { RHOB } \\
\left(\mathrm{g} / \mathrm{cm}^{3}\right)\end{array}$ & $\begin{array}{l}\text { SFLU } \\
(\Omega \mathrm{m})\end{array}$ & $\begin{array}{l}\text { IDPH } \\
(\Omega \mathrm{m})\end{array}$ \\
\hline Silt/siltstone (62) & $59 \pm 5.8$ & $2.2 \pm 0.4$ & $1.3 \pm 0.2$ & $1.4 \pm 0.3$ & $8.3 \pm 1.1$ & $80 \pm 10$ & $1.7 \pm 0.1$ & $1.1 \pm 0.3$ & $1.2 \pm 0.2$ \\
\hline Calcareous silt/siltstone (122) & $58 \pm 4.6$ & $3.4 \pm 0.2$ & $1.3 \pm 0.1$ & $1.6 \pm 0.4$ & $7.7 \pm 0.9$ & $64 \pm 6$ & $1.9 \pm 0$ & $1.1 \pm 0.1$ & $1.1 \pm 0.1$ \\
\hline Silty clay/claystone (594) & $72 \pm 6.1$ & $2.5 \pm 0.4$ & $1.6 \pm 0.2$ & $1.9 \pm 0.6$ & $9.4 \pm 1.3$ & $71 \pm 12$ & $1.8 \pm 0.1$ & $1.4 \pm 0.3$ & $1.4 \pm 0.2$ \\
\hline Calcareous silty clay/clays.(420) & $71 \pm 5.7$ & $3.2 \pm 0.2$ & $1.6 \pm 0.1$ & $2.0 \pm 0.4$ & $9 \pm 1.3$ & $61 \pm 9$ & $1.9 \pm 0.1$ & $1.3 \pm 0.2$ & $1.3 \pm 0.2$ \\
\hline Clay/claystone (1617) & $88 \pm 6.0$ & $2.6 \pm 0.4$ & $1.9 \pm 0.2$ & $2.5 \pm 0.7$ & $11.5 \pm 3.1$ & $60 \pm 17$ & $2.0 \pm 0.7$ & $1.5 \pm 0.4$ & $1.5 \pm 0.2$ \\
\hline Calcareous clay/claystone (563) & $88 \pm 5.9$ & $3.1 \pm 0.2$ & $1.8 \pm 0.2$ & $2.5 \pm 0.5$ & $11.4 \pm 1.3$ & $54 \pm 11$ & $2.0 \pm 0.1$ & $1.6 \pm 0.4$ & $1.6 \pm 0.2$ \\
\hline
\end{tabular}

Note: Number of data points for each electrofacies is given in parentheses. For explanation of the log acronyms see Table 2.

Based on the amount of siliceous and calcareous material, six of the nine electrofacies were distinguished by the SGR and PEF (see also "Downhole Measurements" section, Site 1069, this volume). The six electrofacies are silt/siltstone, calcareous silt/siltstone, silty clay/claystone, calcareous silty clay/claystone, clay/claystone, and calcareous clay/claystone. The lithological profile reconstructed by the logging data is shown in Figure 7. The average log values of these lithologies are given in Table 4. The dominant electrofacies is clay/ claystone, followed by calcareous silty clay/claystone. The minor electrofacies are calcareous silt/siltstone and silt/siltstone.

The depth interval from 770 to $584 \mathrm{mbsf}$ is characterized by clays with interbedding of silty clay and silt. The following interval from 584 to 498 mbsf is composed of relatively homogeneous clay with minor interbedded calcareous clay. The frequent variation in the total gamma ray log indicates sedimentary alternations that might be related to turbidites. The section between 498 and $242 \mathrm{mbsf}$ displays two cycles (1: 498-375, 2: 375-242 mbsf) comparable to those occurring in Hole 1068A. Each cycle starts with silty layers at the base (1:498475, 2: 375-341 mbsf) and toward the top becomes homogeneously clayey. Above $242 \mathrm{mbsf}$, a decrease of the gamma ray and an increase of the PEF mark the transition to the overlying sediments. Above the decrease of the clayey components above 192 mbsf, two upward fining sequences can be distinguished. Above 146 mbsf a continuous decrease of the clay and increase of calcareous material can be recognized.

In general, a good correlation exists between core and logs (Fig. 7). The main rock types occurring in the logged interval in Hole 1069A are calcareous claystone, claystone, nannofossil chalk, and calcareous sandy siltstone in lithostratigraphic Subunit IIB (see "Lithostratigraphy" section, "Site 1069" chapter, this volume).

Discriminant analysis was carried out using the spectral gammaray logs, photoelectric factor, density, porosity, and resistivity logs. In Hole $1069 \mathrm{~A}, 81.01 \%$ of the depth points agreed with the same six manually classified electrofacies. This result indicates a good delineation of the electrofacies.

\section{SUMMARY}

The motivation for this study was to demonstrate the feasibility of presenting detailed log-derived lithology profiles in addition to the core description. Such synthetic profiles are very useful to gain continuous and detailed information about the drilled lithologies. Former studies have successfully proven that the electrofacies concept can establish log-derived lithological profiles in scientific wells (Pechnig et al., 1997; Bremer et al., 1992). The most important step in log interpretation is to learn which lithology is represented by the recorded $\log$ responses. Only when these relations are known and the electrofacies are determined by calibration with core data, then, in a second step, can the transfer of the electrofacies be applied to the data set. This second step can be done manually by distinct thresholds (con- trolled transfer) or by sophisticated tools such as discriminant analysis (Doveton, 1994; Tetzlaff et al., 1989; Delfiner et al., 1987). The work presented here focused on determination of electrofacies; however, the almost complete lack of good calibration sections makes this difficult. Although a detailed core-log integration was not possible, a reasonable match of the log lithology profiles, established by the transfer of the electrofacies, with the lithostratigraphy could be achieved. This confirms the reliable determination of the electrofacies and a good core-log correlation.

As a main result, discriminant analysis confirmed the defined groups (electrofacies) as statistically significant. Furthermore, a transfer of the classified electrofacies of Hole 1069A to unclassified logging data of Hole 1068A was tested. The transfer from Hole $1069 \mathrm{~A}$ to $1068 \mathrm{~A}$ was taken because Hole 1069A is continuously logged and both holes show a largely similar lithostratigraphy (see "Downhole Measurements" section, "Site 1069" chapter, this volume). A comparison of the classification by threshold values and the classification by discriminant analysis is shown in Figure 8. Differences result from misclassification at bed boundaries caused by the vertical resolution of the tools. Downhole measurements used in this study are integrating over an interval of at least $30 \mathrm{~cm}$, which leads to smoothing (shoulder) effects at bed boundaries. A further discrepancy is caused by the classification of thin layers (2-3 depth points) in the discriminant analysis. In contrast, the manual classification integrates the subjective point of view of the investigator who does not separate data points showing only slight variations compared to the adjacent lithology, because these layers are too thin and not significant for a detailed classification.

The target for the future is to build a comprehensive database for an automatic prediction of the lithologic profile in ODP holes.

\section{ACKNOWLEDGMENTS}

We would like to thank V. Louvel and C. Pirmez for critically reviewing this manuscript and A. Newton who spent much time to provide S. Hunze with data at Leicester University. Discussions with H.J. Wallrabe-Adams (GEOMAR) improved our understanding of the drilled lithology. Many thanks go to Dave Goldberg (LDEO), M.O. Beslier, R.B. Whitmarsh, and P.J. Wallace as well as to the Downhole Measurement Panel for supporting the study. We are grateful to Western Atlas International, Inc. for supplying log interpretation software, which was essential for handling the logging data. Financial support by the German Research Foundation (DFG) is gratefully acknowledged.

\section{REFERENCES}

Backhaus, K., Erichson, B., Plinke, W., Schuchard-Ficher, C., and Weiber, R., 1989. Multivariate Analysemethoden. (5th ed.): Berlin (Springer-Verlag). 
Boillot, G., Winterer, E.L., et al., 1988. Proc. ODP, Sci. Results, 103: College Station, TX (Ocean Drilling Program).

Bremer, M.H., Kulenkampff, J., and Schopper J.R., 1992. Lithological and fracture response of common logs in crystalline rocks. In Hurst, A., Griffith, C.M., and Worthington, P.F. (Eds.), Geological Applications of Wireline Logs II. Geol. Soc. Am. Spec. Publ., 65:221-234.

Delfiner, P.C., Peyret, O., and Serra, O., 1987. Automatic determination of lithology from well logs. SPE Form. Eval., 2:303-310.

Doveton, J.H., 1994. Geologic log analysis using computer methods. AAPG Comp. Appl. Geol., 2.

Pechnig, R., Haverkamp, S., Wohlenberg, J., Zimmermann, J., and Burkhardt, H., 1997. Integrated log interpretation in the German Deep Drilling Program: lithology, porosity and fracture zones. J Geophys. Res., 102:18363-18390.

Rider, M., 1996. The Geological Interpretation of Well Logs: Caithness (Whittles Publishing).

Sawyer, D.S., Whitmarsh, R.B., Klaus, A., et al., 1994. Proc. ODP, Init. Repts., 149: College Station, TX (Ocean Drilling Program).
Schlumberger, 1972. Log Interpretation (Vol. 1): New York (Schlumberger). Schlumberger, 1988. Log Interpretation Charts: New York (Schlumberger). Schlumberger, 1989. Log Interpretation Principles/Applications: Houston, TX (Schlumberger Educ. Services).

Serra, O., 1984. Fundamentals of Well-Log Interpretation (Vol. 1): The Acquisition of Logging Data: Dev. Pet. Sci., 15A: Amsterdam (Elsevier).

Serra, O., 1986. Fundamentals of Well-Log Interpretation (Vol. 2): The Interpretation of Logging Data. Dev. Pet. Sci., 15B.

Tetzlaff, D.M., Rodriguez, E., and Anderson, R.L., 1989. Estimating facies and petrophysical parameters from integrated well data. In Transactions, Log Analysis Software Evaluation and Review (LASER) Symposium: London (SPWLA), 1-22.

\section{Ms 173IR-109}

Table 4. Hole 1069A average and standard deviation of log values calculated for the electrofacies determined by log analysis (see text).

\begin{tabular}{|c|c|c|c|c|c|c|c|c|c|}
\hline Electrofacies & $\begin{array}{l}\text { SGR } \\
\text { (API) }\end{array}$ & $\begin{array}{c}\text { PEF } \\
\text { (barn/e) }\end{array}$ & $\begin{array}{l}\text { Potassium } \\
\quad(\mathrm{wt} \%)\end{array}$ & $\begin{array}{c}\text { Uranium } \\
\text { (ppm) }\end{array}$ & $\begin{array}{c}\text { Thorium } \\
(\mathrm{ppm})\end{array}$ & $\begin{array}{l}\text { APLC } \\
(\%)\end{array}$ & $\begin{array}{l}\text { RHOB } \\
\left(\mathrm{g} / \mathrm{cm}^{3}\right)\end{array}$ & $\begin{array}{l}\text { SFLU } \\
(\Omega \mathrm{m})\end{array}$ & $\begin{array}{l}\text { IDPH } \\
(\Omega \mathrm{m})\end{array}$ \\
\hline Silt/siltstone (83) & $57 \pm 10.5$ & $1.6 \pm 0.3$ & $1.2 \pm 0.3$ & $1.8 \pm 0.4$ & $7.4 \pm 1.6$ & $98 \pm 13$ & $1.3 \pm 0.1$ & $1.0 \pm 0.3$ & $1.2 \pm 0.2$ \\
\hline Calcareous silt/siltstone (25) & $62 \pm 7.4$ & $3.5 \pm 0.2$ & $1.4 \pm 0.2$ & $1.6 \pm 0.2$ & $7.8 \pm 1.4$ & $57 \pm 3$ & $1.9 \pm 0.0$ & $1.1 \pm 0.1$ & $1.2 \pm 0.0$ \\
\hline Silty clay/claystone (297) & $75 \pm 5.2$ & $2.4 \pm 0.5$ & $1.6 \pm 0.2$ & $1.9 \pm 0.4$ & $10.2 \pm 1.3$ & $75 \pm 13$ & $1.7 \pm 0.2$ & $1.3 \pm 0.4$ & $1.4 \pm 0.3$ \\
\hline Calcareous silty clay/claystone (336) & $73 \pm 5.8$ & $3.3 \pm 0.3$ & $1.7 \pm 0.2$ & $1.8 \pm 0.5$ & $9.6 \pm 1.3$ & $62 \pm 7$ & $1.9 \pm 0.1$ & $1.1 \pm 0.1$ & $1.1 \pm 0.1$ \\
\hline Clay/claystone (2366) & $97 \pm 10.3$ & $2.6 \pm 0.4$ & $2.0 \pm 0.3$ & $2.5 \pm 0.8$ & $13.4 \pm 2.2$ & $62 \pm 16$ & $1.9 \pm 0.2$ & $1.5 \pm 0.3$ & $1.5 \pm 0.2$ \\
\hline Calcareous clay/claystone (1254) & $96 \pm 10.1$ & $3.1 \pm 0.3$ & $2.1 \pm 0.3$ & $2.5 \pm 0.6$ & $12.9 \pm 2.1$ & $54 \pm 9$ & $2.0 \pm 0.1$ & $1.5 \pm 0.2$ & $1.5 \pm 0.2$ \\
\hline
\end{tabular}

Note: Number of data points for each electrofacies is given in parentheses. For explanation of the log acronyms see Table 2. 

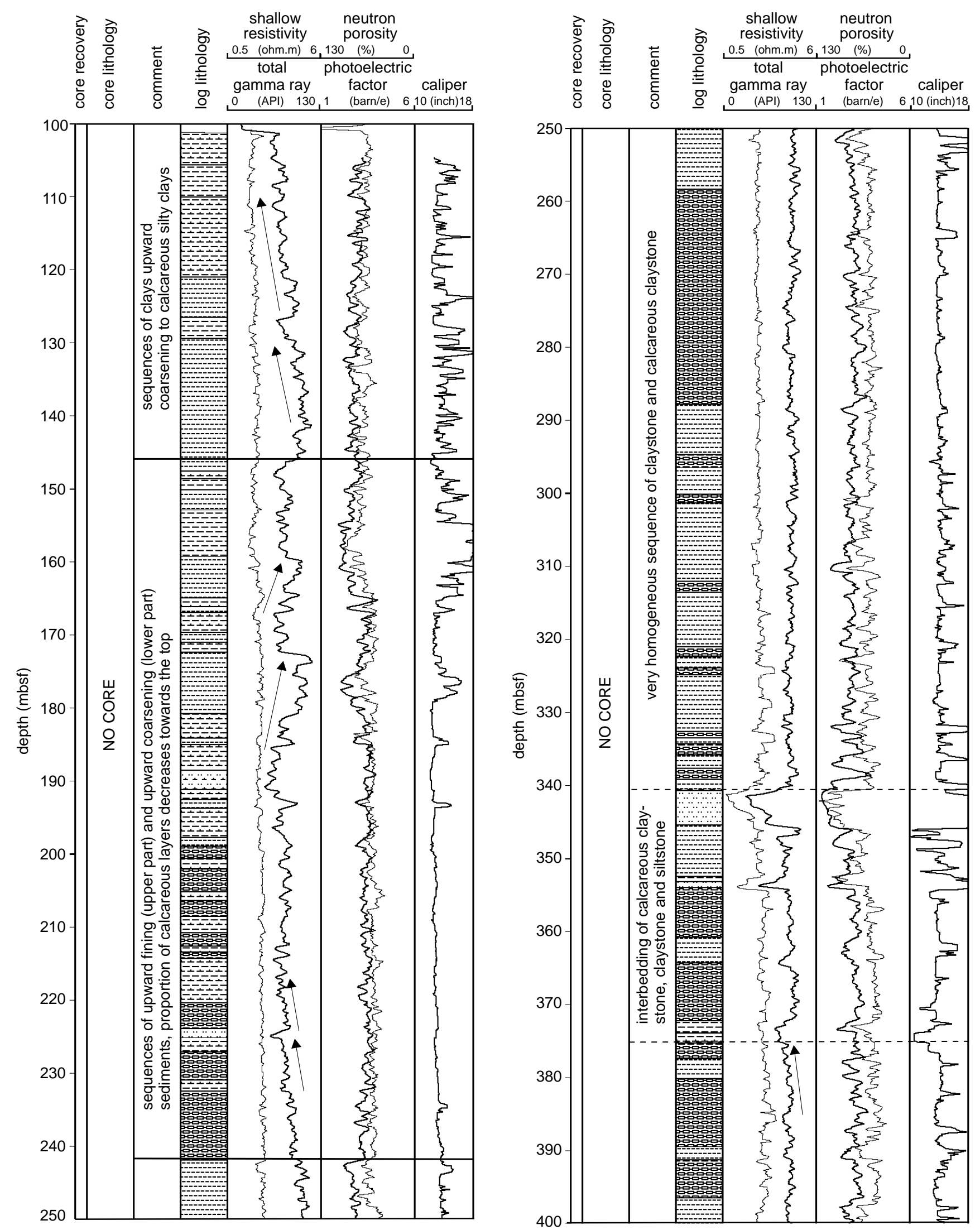

Figure 7. Hole 1069A: lithostratigraphic reconstruction of the drilled lithologies based on the logging data. Arrows mark trends in the logs that can be related to systematic lithological changes. The comments refer to the log lithology column. The left column displays the generalized core lithology that is not as detailed as the core description (see "Lithostratigraphy" section, Site 1069, this volume). For the explanation of the patterns see Figure 5. Differences occur between the generalized core profile and the individual core descriptions. In the generalized profile the lithology is marked as "nannofossil chalk", while in the core descriptions "nannofossil claystone" is the main rock type. SGR and PEF are shown by bold lines. (Continued next page.) 


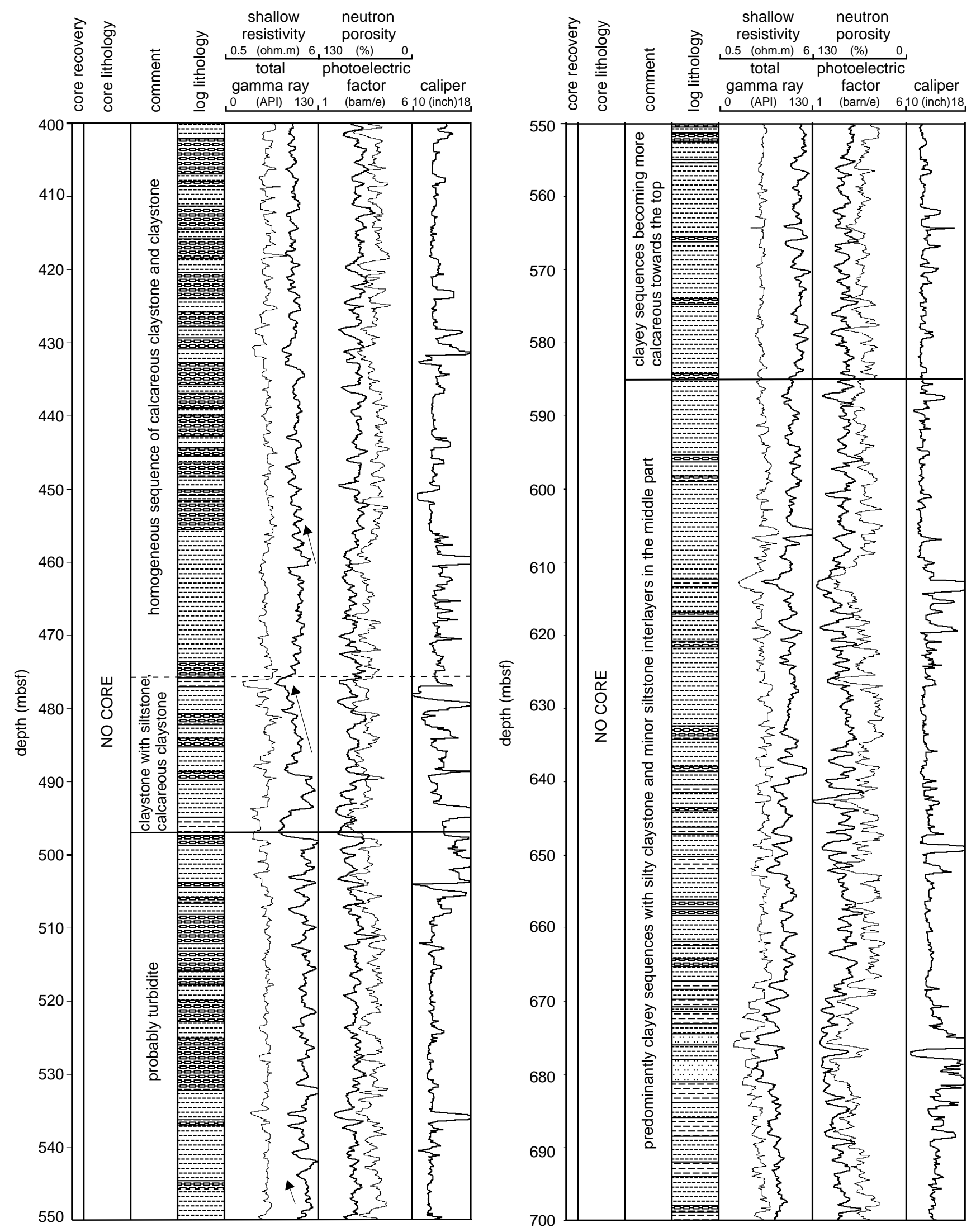

Figure 7 (continued). 


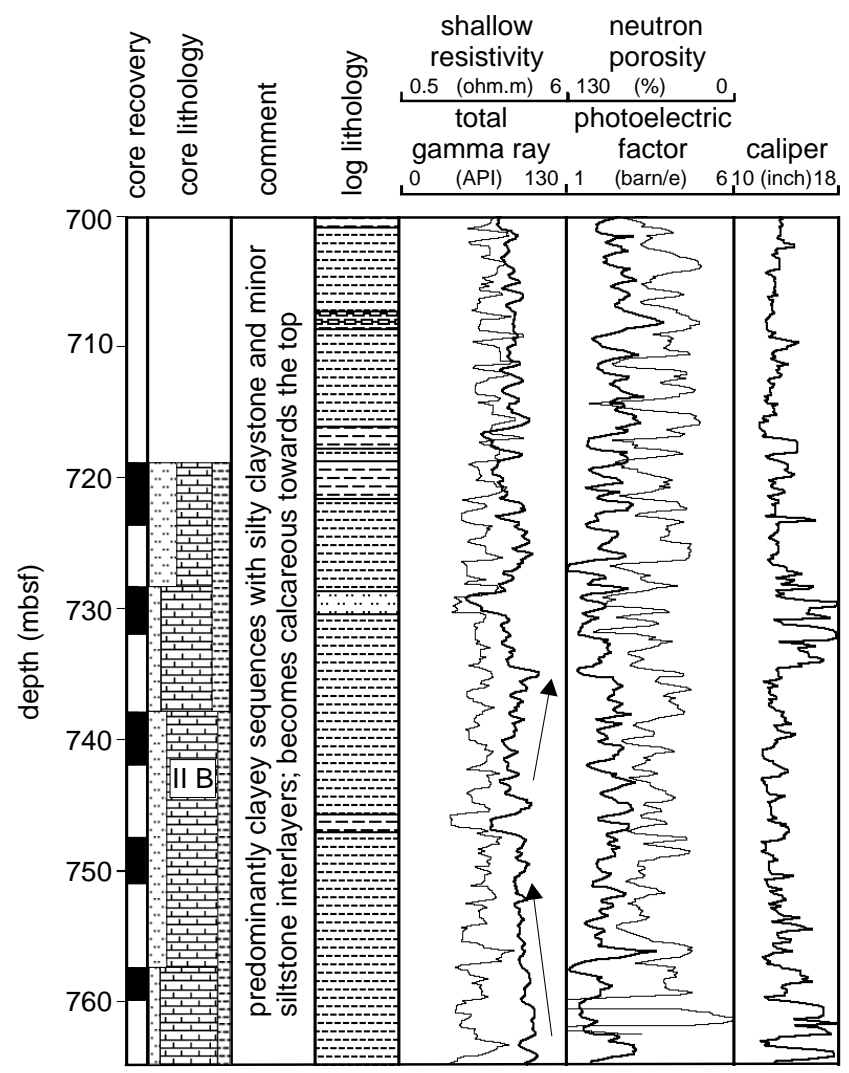

Figure 7 (continued).

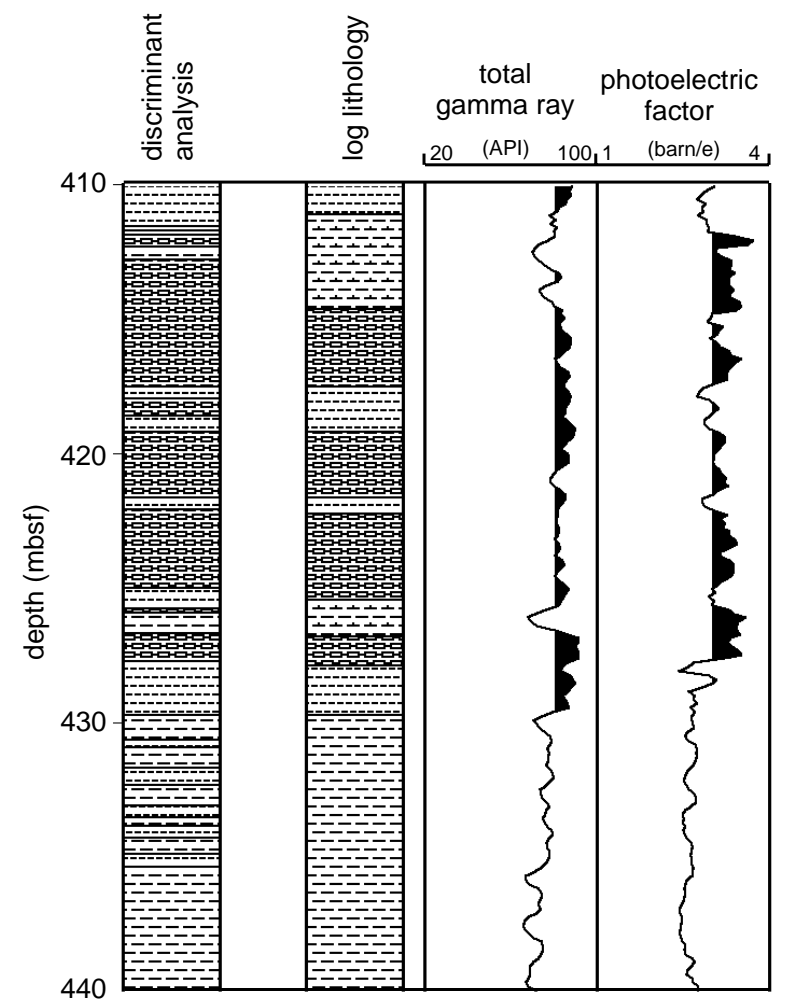

Figure 8. Comparison of the manual classification and the classification calculated by discriminant analysis in Hole 1069A. Differences are caused by shoulder effects at bed boundaries and the more detailed classification of the discriminant analysis. 